\title{
Revisiting Participatory Forest Management and Community Livelihoods in the Kilum-Ijim Montane Forest Landscape of Cameroon
}

\author{
Jude Ndzifon Kimengsi (Corresponding Author) \\ Faculty of Environmental Sciences, Institute of International Forestry \& Forest Products, \\ Technical University of Dresden, 01737, Tharandt, Germany \\ Tel: +49(0)35203-38 31213 E-mail: jude_ndzifon.kimengsi@tu-dresden.de
}

Moteka Paul Ngala

Department of Geography \& Planning, University of Bamenda

P. O. Box 39 Bambili, Cameroon. E-mail: mpngala@yahoo.co.uk

Received: January 10, 2018 Accepted: March 4, 2018 Published: March 6, 2018

doi:10.5296/ijgs.v2i1.12766 URL: http://doi.org/10.5296/ijgs.v2i1.12766

\begin{abstract}
The natural resource -livelihood sustenance link has received significant scientific attention. Specifically, the question of how forests should be managed in relation to the livelihoods of adjacent communities has been one of the burning issues in the field of conservation and rural development. Thus, participation in forest management is not a recent issue in human history. The concept has evolved significantly since the 1970 s due to the alarming rate of deforestation and forest degradation which was registered in most forest regions of the world. Given the significant interest, several approaches to forest management have been applied. For instance, the leviathan approach compelled adjacent communities to adhere to conservation considerations with limited consideration for community livelihoods. Participatory Forest Management (PFM) as a concept has been applied in different contexts with diverse outcomes. Although it is considered relevant in conservation and poverty alleviation, in the context of humid montane forest ecosystems such as the Kilum-Ijim, a scientific analysis of its potential contribution to rural livelihoods is required against the backdrop of increasing demographic pressure and the need to secure livelihoods. In this study, we undertake a systematic sample involving 250 household representatives around the
\end{abstract}


Kilum-Ijim forest Landscape. This was complemented by field observations, interviews of local conservation groups and the consultation of secondary data sources. The data were analysed using the Z-test. The results showed that at 0.05 level of significance, a significant relationship does not exist between aspects of participatory forest management such as tree planting and nursery establishment, and the generation of income in the Kilum-Ijim montane forest landscape. Equally at 0.05 level of significance, a link was established between the creation of forest management institutions and employment generation. Finally, at 0.05 level of significance, there is significant relationship between the exploitation of forest resources and standards of living of communities adjacent to Kilum-Ijim montane forest landscape. The conclusion drawn is that considering the inextricable link between the forest and livelihoods, local coordination efforts should be stepped up to restrict further encroachment into the forest. In addition, trees that are economically and environmentally attractive should be considered during re-afforestation as they can support livelihoods.

Keywords: Participatory forest management, Livelihoods, Conservation, Kilum-Ijim

\section{Introduction}

\subsection{Background}

The question of how forests should be managed in relation to the livelihoods of adjacent communities has been one of the burning issues in the field of conservation and rural development. Thus, participation in forest management is not a recent issue in human history. The concept has evolved significantly since the 1970s due to the alarming rate of deforestation and forest degradation which was registered in most forest regions of the world (Diaw et al., 1997; Davis, 2008). Viewed as a strategy for sustainable resource management and rural poverty alleviation, community forestry initially focused on participatory management in forest regeneration, largely in East Asia and Central America (Bray et al., 2005). The concept was slowly incorporated into tropical and timber abundant forest management, together with increased recognition of the continuing role of forests as common pool resources and the significance of locally led management initiatives. Retrospectively, local communities that served as custodians of forests have proven their potentials to sustainably manage forest resources (Asanga, 2001; Mbenmben, 2007; Enchaw, 2009).

Since the 1970s, development efforts have sought to support and promote community engagement in decision-making through the creation and use of diverse participatory methodologies that gather, analyze and communicate community information. The management strategies adopted are therefore a viable approach for any improvement in the process of forest resource management. By the early 1990s, evidence from the development and testing of institutional approaches in community forestry led to a conviction that devolving forest management to local communities could empower people, reduce poverty and protect forest resources and the environment (Department for International Development, DfID, 2001; Vabi et al., 2002; Pulhin et al., 2009). It is without doubt that forest ecosystems provide human kind with a variety of services thereby reducing poverty. For this reason, most local communities in Africa (Tanzania, Ethiopia, Democratic Republic of Congo, and Cameroon) are empowered to manage and protect forest as a means of alleviating poverty 
and keeping the environment intact. Millions of people worldwide depend on the forest for their livelihoods, in one way or the other; through food consumption and sale, as well as employment from forestry enterprises, services from forest ecosystem, and forest biodiversity (FAO, 2013). Furthermore, 2.6 billion people are estimated to depend on fuel wood for cooking, charcoal making and for energy generation (FAO, 2013). Participatory forest management (PFM) and the sustainable use of natural resources has emerged as one of the challenging issues in the forestry profession.

Participatory forestry refers to the processes and mechanisms that enable those people who have a direct stake in forest resources to be part of decision-making in some or all aspects of forest management, from managing resources to formulating and implementing institutional frame works (Moss et al., 2005). Participatory forest management (PFM) therefore stands as a logical guiding principle in the management of forest and the history of community-managed forest support this fact. Its activities are undertaken in many ways including the creation of tree nursery/planting groups, association of animal grazers, local crafts groups, improved agriculture, additional income generating activities and access to credit as well as group involve in the exploitation of non-timber forest products (Mustalahti, 2006). PFM has an influence on the livelihoods of rural dwellers especially in areas where it is practiced. In this perspective, Chen et al. (2013) argue that increasing participation in forest management projects is not only important for the sustainable use and management of forest resources but also it forms the key premise for sustainable livelihood development of local community in the long run.

The concept of livelihood is inextricably linked with PFM. According to Carney (1998), "a livelihood comprises the capabilities, assets (including both materials and social resources) and activities required for a means of living. A livelihood is sustainable when it can cope with and recover from stresses and shocks and maintain or enhance its capabilities and assets both now and in the future while not undermining the natural resource base". Scoones (1998) divides livelihood assets into five different types of capital i.e. natural, human, social, financial and physical capital and Ellis (2000) talked of the physical capital; human and social capital represents community cohesion, networks and community involvement in the process. Natural capital represents natural resources. For the communities adjacent to Kilum-Ijim forest, some of these natural resources are water, forest products and climatic conditions. The economic or financial capitals are internal tangible assets such as cash, savings, technology and material in the household and external assets such as infrastructure. These capitals in the case of Kilum-Ijim montane forest area have greatly improved on the standards of living of the indigenes. The focus of this work is therefore on the natural, economic and social assets which are relevant in improving livelihoods and standard of living of forest adjacent communities. Although PFM is said to be a driving factor for rural livelihoods, there is a need to investigate this claim within the context of the Kilum-Ijim forest area which represents a rich montane ecosystem in the North West of Cameroon.

\subsection{Problem Setting}

The link between natural resources and livelihoods sustenance has been a subject of scientific interest and debate. This is particularly true in forest resource management where concerns 
are expressed on the adequate methods to link forest management and livelihoods. Such concerns have been expressed in the Millennium Development Goals (goal 7 i.e. ensure environmental sustainability) and are further captured in the Sustainable Development Goals (SDGs). For instance, SDG1 stressed on the need to end poverty in all its forms everywhere while SDG15 centered on the need to protect, restore and promote the sustainable use of terrestrial ecosystems, sustainably manage forests, combat desertification, and halt and reverse land degradation and halt biodiversity loss. Given the significant interest, several approaches to forest management have been applied. This saw the introduction of centralized and leviathan approaches which compel adjacent communities to adhere to conservation considerations. The failure of these approaches to yield significant results perhaps culminated to the search for more realistic ones. Participatory Forest Management (PFM) therefore emerged as one of the approaches. PFM has been prominent as a concept due to the increasing need to improve forest resource management (Mustalahti, 2007; Mustalahti, 2005; White \& Mustalahti, 2005). It has been seen in many perspectives as a solution because it engages the local adjacent forest communities in forest management. As a result of this, the concept has gained international significance with many forested countries subscribing to the initiative. Cameroon being the $8^{\text {th }}$ most forested country in the world with a host of over 30 forest reserves or protected areas considers this concept relevant in providing support for the sustainable management of forest resources. In this respect, Law No 94/01 of January $20^{\text {th }}$ 1994 on the regime of forestry, wild life and fisheries were all enacted followed by their decree of application to see how they can improve on the management of forest resources. It is in this regard that much attention has been given in the area of local people's participation in the management of natural resources. Although PFM is considered as relevant in conservation and poverty alleviation, in the context of humid montane forest ecosystems such as Kilum-Ijim, a scientific analysis of its potential contribution to rural livelihoods needs to be ascertained. In the case of the Kilum-Ijim montane forest environment, significant research focus has been directed towards the assessment of the role of community participation in rural development (Ndenecho, 2012; Fogwe \& Kwei, 2015). Further attention has equally been given to the challenges involved in forest resource management. With increasing demographic pressure and continued degradation of the forests, a study which identifies and establishes ways to link PFM and livelihoods is even more pertinent. The goal of this study is to re-echo the link between participatory forest management and livelihoods in a bid to shape local level conservation policy and politics.

\section{Contextual Literature}

PFM resource management systems have gained significant research and policy attention in the recent past. PFM has been introduced in some parts of the world with varying degrees of success. In Nepal, its introduction contributed to biodiversity improvement as a $51 \%$ increase in the total number of stems per unit was recorded, leading to an improvement in biodiversity and ecological conservation (Branney \& Yandav, 1998). Furthermore, Canari (2002) reported that in the Caribbean, a review of existing cases give evidence of some significant positive impacts, as well as unanticipated negative ones. Resource degradation has been reversed and ecosystem health restored through stabilized utilization patterns and control of overuse. 


\section{Macrothink}

Although PFM has not been institutionalized within the Ethiopian state structure, visible impacts have been observed through improved forest conditions (Irwin, 2004). In Tanzania, it supported the improvement of livelihoods on the one hand, and conservation on the other hand (Kajembe et al., 2004). Negative effects were equally observed around the Kwizu Forest Reserve in Kilimanjaro region of Tanzania, where-by despite the PFM strategy, illegal activities in the reserve are still extensive, and forest exploitation has increased. Mohamed (2006) also observed a non-significant positive impact on resource base especially basal area and standing wood volume in Handeni Hill Forest Reserve. Although very few studies have been conducted with regards to the ecological impact of PFM in India, there are indicators of a positive impact of PFM across the country. In many states, forests under PFM are regenerating, productivity and vegetal diversity is increasing while local communities feel more satisfied (Murali et al., 2002; Ravindranath \& Sundha, 2004). In Cameroon for instance, the Banyang-Mbo Wildlife Sanctuary (BMWS) project which sought to integrate local people in the conservation of the BMWS and its resources for the interest of local communities (Nkembi, 2003) has registered mixed outcomes. As human population increase and the demand for resources grow, the frequency and intensity of conflict between the forest areas and local people also increases due to increasing human needs and the overexploitation of resources within these area, more workable approaches are required to avoid and/or mitigate conflicts while supporting conservation and livelihood efforts. For this to be effective, the relationship between local people and the forest must be understood in terms of their livelihoods (Nambu, 2001).

The concept of Participatory Forest Management (PFM) is very vital for sustainable forest exploitation. Vital components such as tree nursing/planting, creation of FMIs as well as the exploitation of forest products are important indicators of sustainable forest management. This is because local people adjacent to Kilum-Ijim montane forest undertake income generating activities within the forest like bee keeping, fuel wood, medicinal plants extraction, food, cattle, sheep and goat rearing and raw materials for weaving, carving and construction. These activities help the local people to generate income through the sales of their products. With this income generated from the forest, their living standard is improved and their attitude towards forest exploitation and management will change. The change in attitude is directed towards the sustainable management and exploitation of the forest so as to maintain the forest resource base. There has been a genuine shift of management over natural resources in general from government authority to local people. PFM is considered as an overall term for decentralized forest management models, irrespective of tenure. Under this dispensation, communities effectively contribute to develop objectives, plans and rules for the use and management of village or community forests, among others (Mustalahti, 2006, White \& Mustalahti, 2005). Mustalahti (2006) proposes a "house model" as a panacea to participatory forest management which ushers in long term benefits for communities (Figure 1). 


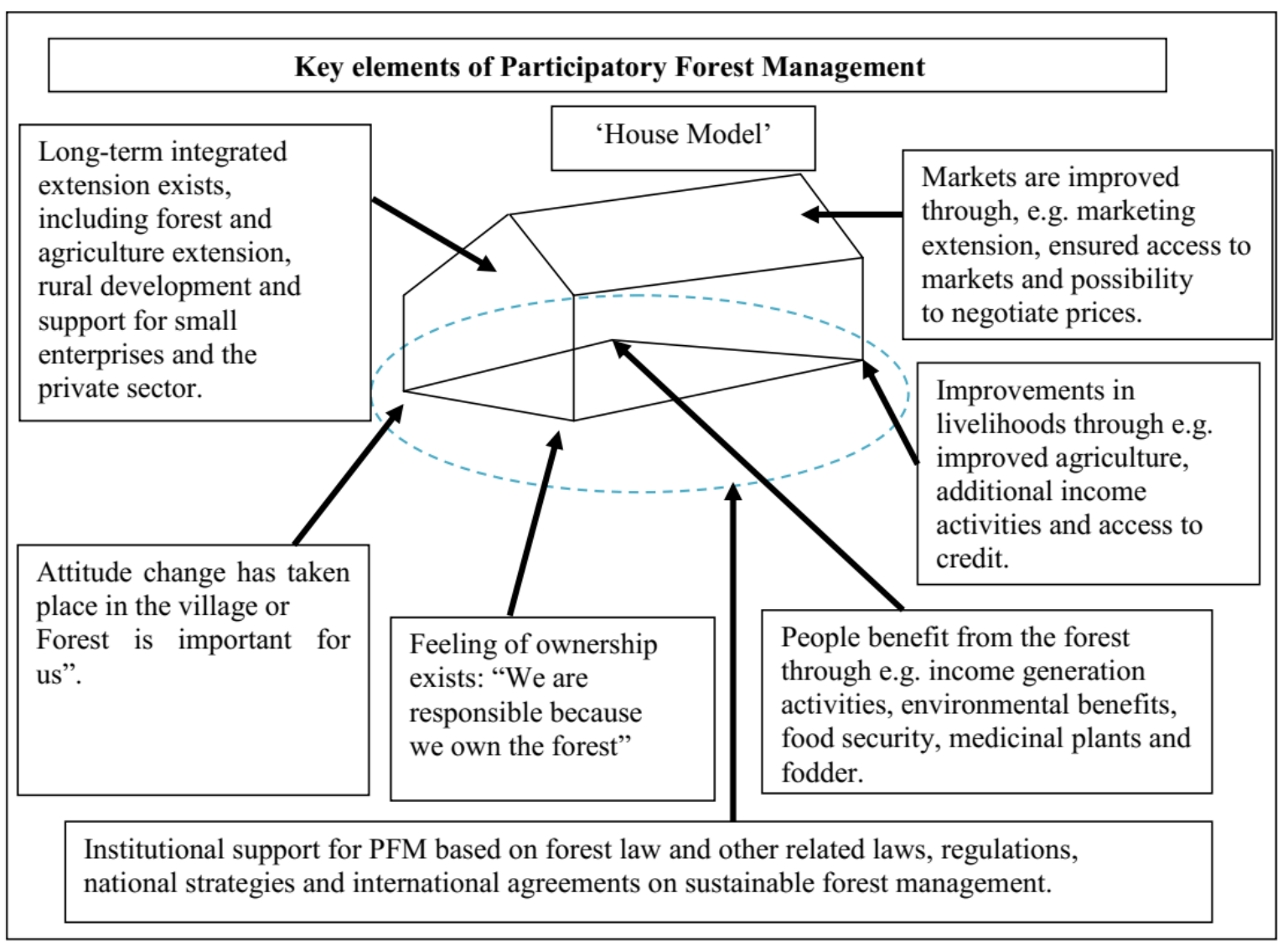

Figure 1. Framework on Participatory forest management - the "House Model" Source: Mustalahti, 2006.

PFM is construed as 'a building site' with 'four corner stones', 'walls' and a 'roof'. The supportive institutions, laws and policy environment form the building site, and the corner stones are: (a) attitude change towards forests, (b) feelings of ownership of forest resources, (c) benefits from forest, and (d) general improvement in livelihoods (Mustalahti, 2006). The walls stand for long-term extension service provision which includes different areas of rural development and provides needed information. The roof represents markets for forest products and other products and services from the area, for example environmental services which are paid by government or foreign funds. In the Kilum-Ijim montane forest landscape, people benefit from the forest through income generation activities, environmental benefits, food security, medicinal plants and fodder and also improvements in livelihoods through improved agriculture, additional income activities and access to credit. These benefits are largely visible for households that are linked to conservation NGOs. This serves as a limitation as other community members who constitute the majority may not have significant indirect benefits through PFM.

\section{Study Area and Research Methodology}

Kilum and Ijim Mountain Forest Projects were created in 1987 and 1992 respectively, in order to reduce the rate of forest loss and ensure its sustainable management. Since 1995, the two projects have been joined together as the Kilum-Ijim (Kilum-Ijim forest Project, 1994). 


\section{Macrothink}

The landscape forms part of the Western Highlands of Cameroon (Figure 2).

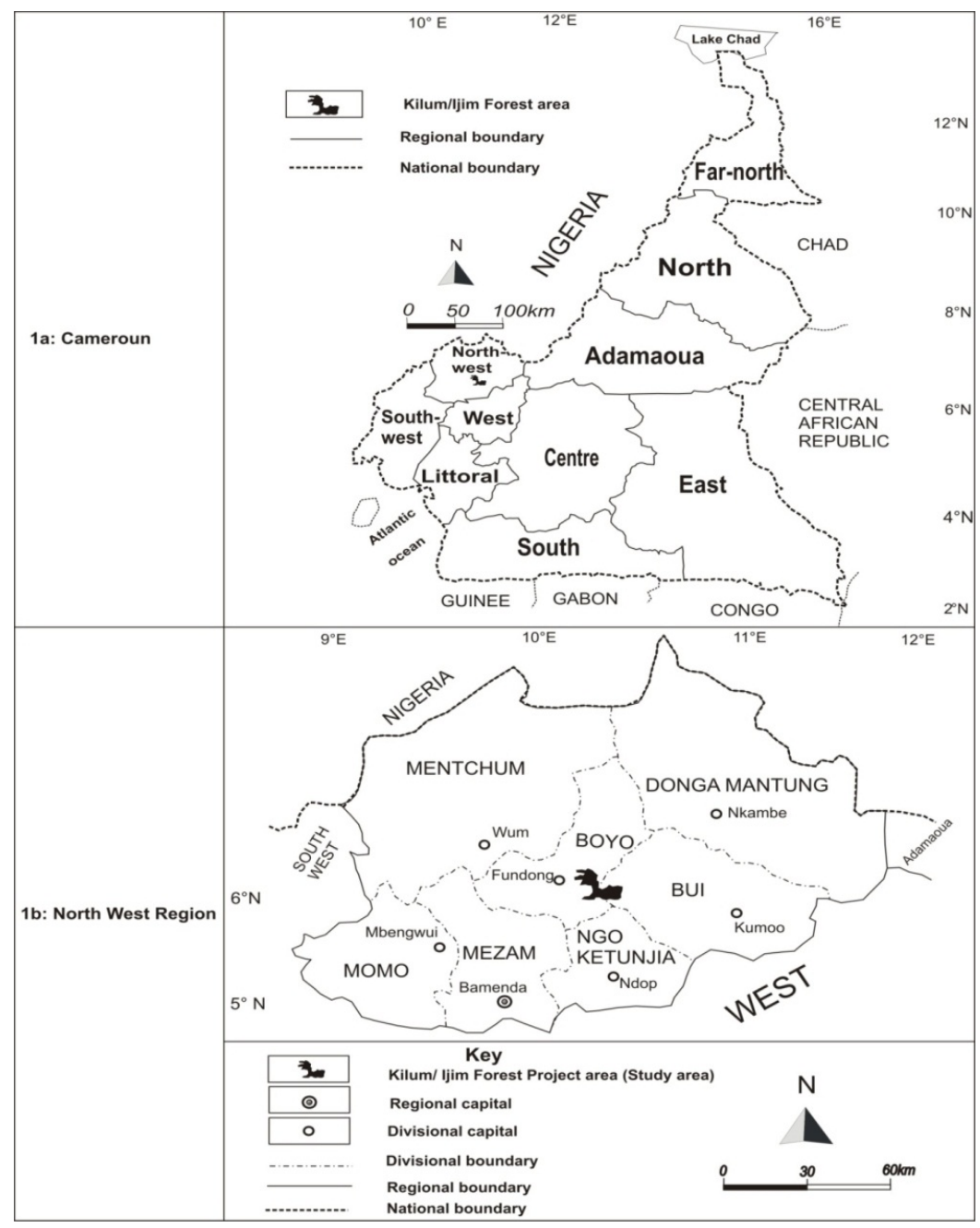

Figure 2. Location of Kilum-Ijim Forest in Cameroon \& the NW Region

Source: Adapted from the administrative map of Cameroon.

It is a contiguous landscape which cuts across Kilum (Bui Division) and Ijim (Boyo Division) of Cameroon with grid reference of $6^{\circ} 12^{\prime} \mathrm{N}, 10^{\circ} 23^{\prime} \mathrm{E}$ and Lake Oku $6^{\circ} 12^{\prime}, 10^{\circ} 27^{\prime} \mathrm{E}$ (Ndenecho 2012). The northern part of the forest is known as the Kilum Mountain by Oku villages while the southern part is called Ijim or Ejim forest by the Kom villages. Generally, geographers refer to the mountain as Mount Oku. The forest is found mainly between $2022 \mathrm{~m}$ and $3011 \mathrm{~m}$ above sea level. Geographically, the study area forms part of the Cameroon highland eco-region which encompasses the mountains and highland areas of the border region between Nigeria and Cameroon (Stuart, 1986; Gartland, 1989; Stattersfield, 1998). It should be borne in mind that Mount Oku is at an altitude of $3011 \mathrm{~m}$ above sea level. In phyto-geographical classification, Kilum-Ijim forest falls within Afro-montane archipelago-regional center of endemism that spans the entire continent (White, 1983). Macleod (1986) estimates that in 1963, there were approximately 17500 hectares of forest. According to the 2005 national population census, the human population of the area stood at 85169. With an increase of above $2.5 \%$ per annum, the population is estimated at 126,426 
inhabitants as of 2016 (Oku municipal council statistics, 2015). Agriculture is the main economic activity of the region and about $90 \%$ of the population is directly engaged in agricultural activities (Agricultural Annual Report of Bui and Boyo, 1994-1995). Besides agriculture, $10 \%$ of the population in the area is engaged in other local activities like carving, hunting, embroidery and blacksmithing which are all forest dependent activities. There has also been the establishment of small scale industries such as the honey processing, coffee milling and numerous furniture workshops. This population is distributed in 43 villages.

The research design used for this study is a case study, survey and cross-sectional design which were employed to collect information from forest users of different age/sex groups of the population. The case study is used to study a particular case in point with a view to examining in great depth and extent the characteristics of that individual unit (Issa 2004). Some of the instruments used in collecting data for case studies include observation, questionnaires, interviews as well as documentary sources. With respect to the cross-sectional research design, sample techniques were used and inferences made as well about the target population. The main objective here is to seek the opinions of individuals on a particular problem, whereby the consensus of their opinions provides the needed solution to the problem at hand. This research therefore is a case study that has to do with Participatory Forest Management activities and Implications on Livelihoods with reference to the Kilum-Ijim montane forest landscape. This method is used in studying a particular case in point with the view of examining in great depth and extent the characteristics of that individual unit which is the Kilum-Ijim montane forest. A total of 250 questionnaires were distributed to the respondents using a systematic sampling technique. Data analysis was aided by the Statistical Package for Social Sciences (SPSS) version 21.0 (SPSS, Inc.2012). Descriptive statistics was used to present the distribution of respondents while the z-test was employed to verify the link between participatory forest management and livelihoods at 0.05 level of significance. The formula for the $\mathrm{Z}$ test is as follows;

$$
\mathrm{Z}=\frac{\bar{x}-\mu_{0}}{\sigma / \sqrt{\eta}}=\frac{\text { the sample mean }- \text { the hypothestzed true population mean }}{\text { the sample standard devtation } / \sqrt{\text { the sampie slze }}}
$$

\section{Results and Interpretation}

\subsection{Tree Nursery/Planting and Income Generation}

Figure 3 shows a statistical relationship between the activities of tree nursing/planting and income generation in the Kilum-Ijim montane forest landscape. Workers paid to take care of young planted trees have the highest frequency representing 82 percent followed by paid workers employed to work in the nurseries with frequency of 80 percent. Respondents who are workers paid to plant trees and those transporting tree seedlings for planting involving payment each had 79 percent respectively. 


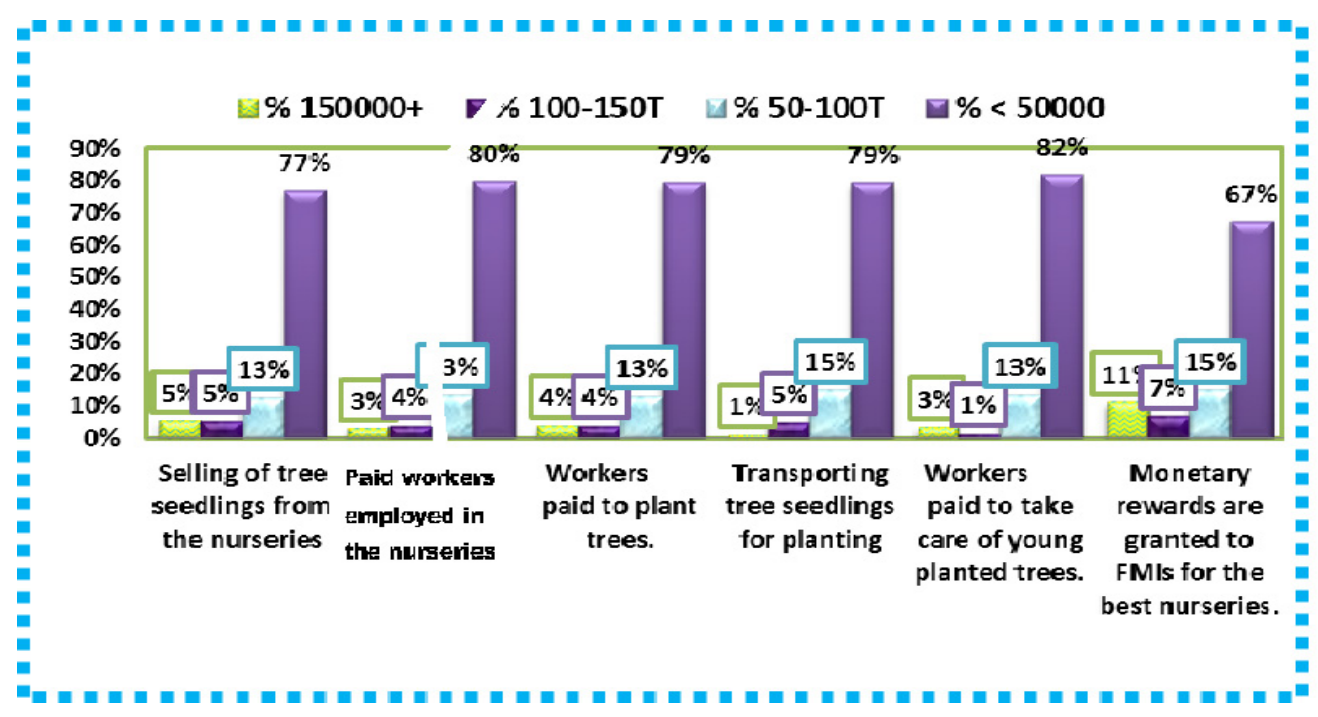

Figure 3. Average monthly income generated from tree Nursery/planting

Source: Field Data, 2017.

Figure 3 also shows that the frequency of those selling tree seedlings from the nurseries scored 77 percent whereas monetary rewards granted to FMIs for the best nurseries represented 67 percent. It should be noted that NGOs such as CAMGEW always grant monetary rewards to the best nurseries annually. The $\mathrm{Z}$ test was conducted to analyse the relationship between the tree nursing/planting income generation in the Kilum-Ijim montane forest landscape (Table 1).

Table 1. Z-test Values for tree Nursing/Planting and Income Generation

\begin{tabular}{|c|c|c|c|c|c|}
\hline Label & Mean & SD & Df & Z-cal & Final Dec \\
\hline $\begin{array}{l}\text { Selling of tree seedlings from the } \\
\text { nurseries generate income. }\end{array}$ & 1.3894 & 0.8149 & 207 & -19.7 & NS \\
\hline $\begin{array}{l}\text { Paid workers are employed to work in the } \\
\text { nurseries. }\end{array}$ & 1.2981 & 0.6793 & 207 & -25.5 & NS \\
\hline Workers are paid to plant trees. & 1.3221 & 0.7270 & 207 & -23.4 & NS \\
\hline $\begin{array}{l}\text { Transporting tree seedlings for planting } \\
\text { involve payment. }\end{array}$ & 1.2740 & 0.5954 & 207 & -29.7 & NS \\
\hline $\begin{array}{l}\text { Workers are paid to take care of young } \\
\text { planted trees. }\end{array}$ & 1.2644 & 0.6537 & 207 & -27.3 & NS \\
\hline $\begin{array}{l}\text { Monetary rewards are granted to FMIs for } \\
\text { the best nurseries. }\end{array}$ & 1.6154 & 1.0197 & 207 & -12.5 & NS \\
\hline
\end{tabular}

At 0.05 level of significance, the results showed a Z- calculated value of -23.00 at 207 degrees of freedom which is less than the $Z$ table value of 1.6449. The conclusion drawn therefore is that there exists no significant relationship between the nursing/planting of trees 


\section{Macrothink}

and generation of income in the Kilum-Ijim montane forest landscape. This implies that the nursing/planting of trees does not generate any significant income to those involve in this activity. The results are considered tenable as very few people adjacent to the forest are involved in agroforestry as well as in the buying and planting of tree species for their personal use or afforestation of the Kilum-Ijim montane forest.

\subsection{Forest Management Institutions (FMIs) and Employment Generation}

FMIs have existed in the Kilum-Ijim forest area since the 90s when Birdlife International was in charge of managing the forest. These FMIs created jobs as workers were recruited to take charge of the forest management. Figure 4 reveals that respondents who agreed that Nursing/planting of trees by groups offer employment occupies the highest frequency with 90 percent while those that disagreed occupied 7 percent and neutral 3 percent. Those who agreed with the option that traditional institutions help in reinforcing forest laws followed with the frequency of 89 percent while 88 percent of the respondents represent the frequency for Local craft groups also create employment. The figure also shows that the respondents who are of the options that forest management is reinforced by employment of forest guards and the idea associations for the extraction of forest product create employment occupied the frequency of 86 percent respectively. This is followed by 84 percent for workers employed in forest management institutions helping in reinforcing forest laws, 76 percent for NGOs also recruit workers for fire-tracing and 74 percent for grazers associations employ workers to control grazing in the forest, respectively. In addition to the direct employment opportunities analyzed above, indirect employment aspect of the forest can also be analyzed. Workers employed in honey cooperatives sustain their livelihoods by working in these cooperatives though not directly involve in forest exploitation. 

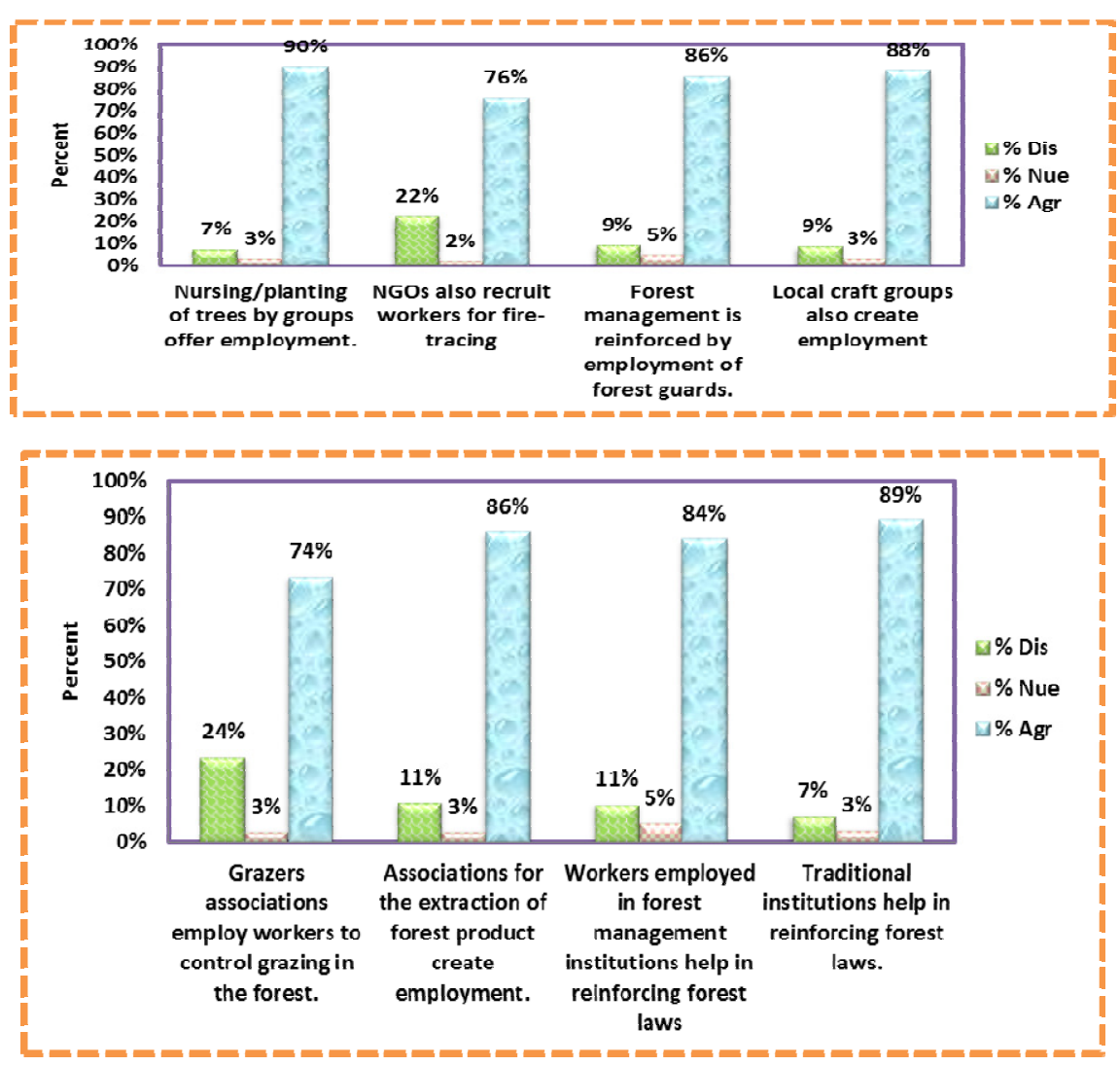

Figure 4. Forest management institutions and employment generation

Source: Field survey, 2017.

During an interview with the Manager of Oku Honey Cooperative (OHC), it was revealed that they are able to generate above ten million francs CFA (10m FCFA) as income. This money is used to pay its workers as well as to purchase honey from those they consider to be "users". Users are those bee farmers who are not members to the honey cooperatives but only come to weigh their products during harvesting seasons. These cooperatives have access to credit from local financial institutions. Other aspects of indirect employment include those who are employed to work as tourist guides, transporters of arts and crafts as well as traders in medicinal plants (e.g. prunus africana) and livestock farming. The $\mathrm{Z}$ test results for employment generation and the creation of FMIs is presented in Table 2. 


\section{Macrothink}

Table 2. Z-test Value for employment generation and the creation of FMIs

\begin{tabular}{|c|c|c|c|c|c|}
\hline Label & Mean & $\mathrm{SD}$ & df & Z-cal & Final Dec \\
\hline $\begin{array}{l}\text { Nursing/planting of trees by groups offer } \\
\text { employment. }\end{array}$ & 4.37 & 0.92 & 207 & 21.52 & SIG \\
\hline NGOs also recruit workers for fire-tracing & 3.84 & 1.28 & 207 & 9.41 & $\mathrm{SIG}$ \\
\hline $\begin{array}{l}\text { Forest management is reinforced by } \\
\text { employment of forest guards. }\end{array}$ & 4.20 & 1.01 & 207 & 17.23 & SIG \\
\hline Local craft groups also create employment & 4.24 & 0.98 & 207 & 18.20 & SIG \\
\hline $\begin{array}{l}\text { Grazers associations employ workers to } \\
\text { control grazing in the forest. }\end{array}$ & 3.77 & 1.22 & 207 & 9.15 & SIG \\
\hline $\begin{array}{l}\text { Associations for the extraction of forest } \\
\text { product create employment. }\end{array}$ & 4.07 & 1.05 & 207 & 14.67 & SIG \\
\hline $\begin{array}{l}\text { Workers employed in forest management } \\
\text { institutions help in reinforcing forest laws }\end{array}$ & 4.06 & 1.00 & 207 & 15.24 & SIG \\
\hline $\begin{array}{l}\text { Traditional institutions help in reinforcing } \\
\text { forest laws. }\end{array}$ & 4.26 & 0.90 & 207 & 20.21 & SIG \\
\hline
\end{tabular}

At 0.05 level of significance, the Z-calculated value of 15.70 at 207 degrees of freedom is greater than the Z-value of 1.6449. The results indicate that employment generation is linked to the creation of FMIs within the Kilum-Ijim forest landscape. This implies that there are some FMIs that offer employment opportunities within communities adjacent to landscape to support household welfare.

\subsection{Forest Product Exploitation and Livelihoods}

In the Kilum-Ijim montane forest area, there is a significant relationship between the exploitation of forest products and livelihoods. This is due to the fact that majority of the communities found around this forest depend on the exploitation of forest products for their livelihoods. The information in Figure 5 reveals that respondents who agreed that benefits from a variety of works of arts occupies the highest frequency with 93 percent while those that disagreed occupied 4 percent and neutral 3 percent respectively. Those who agreed with the statement that water catchment protection/conservation and bee keeping followed with the frequency of 92 percent each while 90 percent of the respondents represent the frequency for firewood collection. 

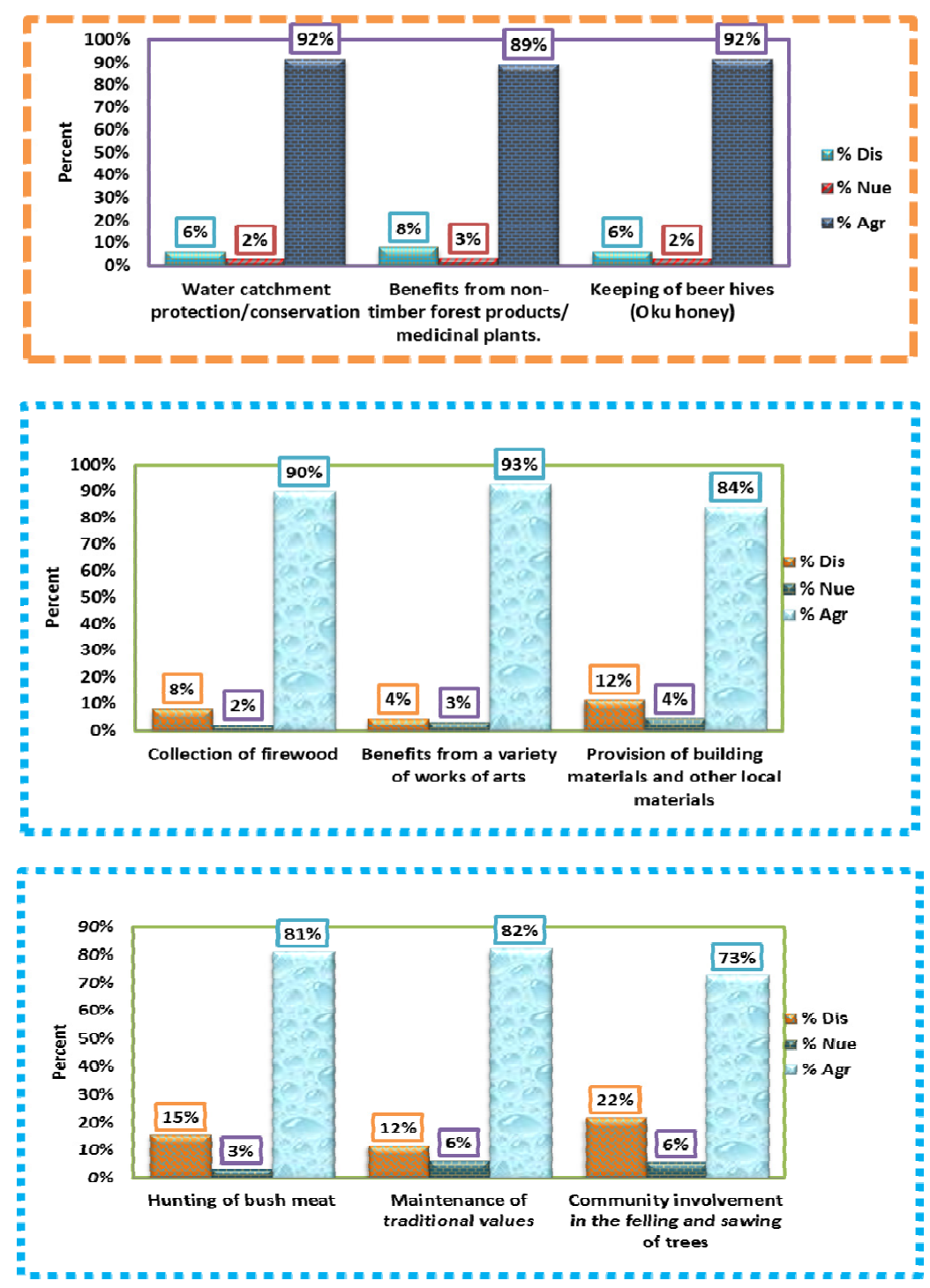

Figure 5. Forest Management and community well-being

Source: Field Data, 2017

The figure also shows that the respondents who are of the option that the benefits from a variety of works of arts occupied the frequency of 89 percent while provision of building and other local materials occupied the frequency of 84 percent. This is followed by 82 percent frequency for the statement that the forest assists in the maintenance of traditional values while hunting of bush meat occupied 81 percent frequency and 73 percent for Community involvement in the felling and sawing of trees. The $\mathrm{Z}$ test results for forest exploitation and community well-being is presented in Table 3. At 0.05 level of significance, the results showed that the Z-calculated value of 18.12 at 207 degrees of freedom is greater than the Z- table value of 1.6449. This indicates that there is significant relationship between the exploitation of forest resources and the well-being of communities adjacent to Kilum-Ijim montane forest landscape. This implies that the exploitation of forest resources greatly helps in generating income that is used by the communities in purchasing their basic needs. The exploitation of resources such as fuel wood and building materials directly help to sustain the daily needs of 


\section{Macrothink}

International Journal of Global Sustainability

ISSN 1937-7924

2018, Vol. 2, No. 1

households around this forest area. That is why communities around Kilum-Ijim forest are gradually getting involve in various aspects of PFM activities.

Table 3. Z-test values for forest resources exploitation and community well-being

\begin{tabular}{|c|c|c|c|c|c|}
\hline Label & Mean & SD & Df & Z-cal & Final Dec \\
\hline $\begin{array}{l}\text { Water catchment } \\
\text { protection/conservation }\end{array}$ & 4.58 & 0.90 & 207 & 25.19 & SIG \\
\hline $\begin{array}{l}\text { Benefits from non-timber forest } \\
\text { products/ medicinal plants. }\end{array}$ & 4.40 & 0.97 & 207 & 20.85 & SIG \\
\hline Keeping of beer hives (Oku honey) & 4.50 & 0.89 & 207 & 24.23 & SIG \\
\hline Collection of firewood & 4.30 & 1.03 & 207 & 18.23 & SIG \\
\hline Benefits from a variety of works of arts & 4.42 & 0.86 & 207 & 23.89 & $\mathrm{SIG}$ \\
\hline $\begin{array}{l}\text { Provision of building materials and other } \\
\text { local materials }\end{array}$ & 4.15 & 1.12 & 207 & 14.78 & SIG \\
\hline Hunting of bush meat & 3.99 & 1.13 & 207 & 12.65 & SIG \\
\hline Maintenance of traditional values & 4.09 & 1.05 & 207 & 14.92 & SIG \\
\hline $\begin{array}{l}\text { Community involvement in the felling } \\
\text { and sawing of trees }\end{array}$ & 3.76 & 1.30 & 207 & 8.40 & SIG \\
\hline
\end{tabular}

\section{Conclusion and Recommendations}

The objective of this study was to analyse the relationship between participatory forest management and livelihoods of communities around the Kilum-Ijim montane forest landscape of Cameroon. The study employed the use of semi-structured questionnaire to generate data for analysis using the Z-test. Based on the empirical analysis, the following conclusions can be drawn: At 0.05 level of significance, a significant relationship does not exist between aspects of participatory forest management such as tree planting and nursery establishment, and the generation of income in the Kilum-Ijim montane forest landscape; equally, at 0.05 level of significance, a significant relationship exists between the creation of forest management institutions and employment generation for communities around the Kilum-Ijim montane forest landscape; finally, at 0.05 level of significance, there is significant relationship between the exploitation of forest resources and the well-being of communities adjacent to Kilum-Ijim montane forest landscape. Based on the conclusions drawn, it is imperative to recommend the following: Considering the inextricable link between the forest and livelihoods, local coordination efforts should be stepped up to restrict further encroachment into the forest. Furthermore, trees that are economically and environmentally attractive should be considered during re-afforestation as they can support livelihoods. Most communities lack the means to acquire the inputs to run tree nurseries and they equally lack the knowledge to undertake such. Technical and financial support from the state and other 
conservation actors will go a long way to improve on the situation. Partnerships between the government and other conservation organizations should be strengthened to coordinate interventions to improve afforestation, bee keeping, and training of local community groups.

\section{Acknowledgement}

The authors acknowledge the contributions of research assistants during the data collection phase of the study. We equally acknowledge the financial support received under TU Dresden's Institutional Strategy, through the Excellence Initiative of the Federal and State Governments.

\section{References}

Asanga, C. (2001). Facilitating Viable Partnerships in Community Forest Management in Cameroon: the case of Kilum-Ijim mountain forest area. In E. Wollenbeng, D. Edmunds, L., Buck, J. Fox, \& S. Brodt (Eds.) Social Learning in Community Forests, CIFOR/East-West Center.

Branney, P., \& Yadav, K. P. (1998). Changes in community forest condition and management 1994-1998: Analysis of information from the forest resource assessment study and socioeconomic study in Koshi Hills. Nepal-UK community forestry project. Project report G/NUKCFP/32, Kathmandu.

Bray B. D., Merino-Perez L., \& Barr, D. Eds. (2005). The community forests of Mexico: Managing for sustainable landscapes (1st ed.). Texas: University of Texas Press.

Canari. (2002). Participatory forest management in the Caribbean: Impacts and potentials. Caribbean Natural Resources Institute, Policy Brief No.1 John D and MacArthur Foundation, Trinidad and Tobago.

Chen, H., Zhu, T., Krott, M., \& Maddex, D. (2013). Community forest management and livelihoods development in the northwest China; Integration of governance, project design and community participation. Regional Environmental Change: Springer-Verlag, 13(1), 67-75. https://doi.org/10.1007/s10113-012-0316-3

Carney, D. (ed) (1998). Sustainable rural livelihoods. What contributions can we make? DFID, London, UK

DFID. (2001). How forests can reduce poverty. Rome: Department for International Development (DFID), Food and Agriculture Organisation of the UN (FAO).

Davis, E. J. (2008). New promises, new possibilities? Comparing community forestry in Canada and Mexico. BC Journal of Ecosystems and Management, 9(2), 11-25.

Diaw, M. C., Assoumou, M. H., \& Dikongue, E. (1997). Community management of forest resources: conceptual developments and institutional change in the humid forest zone of Cameroon. Paper presented at the EPHTA - Eco-regional Programme for the Humid and Subhumid Tropics of Africa, Launching of the Forest Margins Benchmark, Yaoundé Hilton, May 26-27, 1997.

Ellis, F. (2000). Rural livelihoods and diversity in developing countries. Oxford: Oxford University Press.

Enchaw, G. B. (2009). An Assessment of Conservation Strategies in the Management of 
Natural Resources in Kilum-Ijim Forest Project area (NWR of Cameroon), July, 2009.

Fogwe, N., \& Kwei, J. (2015). Cameroonian protected Kilum-Ijim forests for the development of Oku forest fringe community. E3 Journal of Environmental Research and Management, University of Bamenda.

FAO. (2013). Contribution of forests to food security needs more attention- Conference on Forests and Nutrition calls for secure tenure for small holders, FAO, Rome.

Irwin, B. C. (2004). Developing participatory forest management in Ethiopia through a process oriented experimental approach: The experience of FARM Africa, SOS Sahel and GTZ. A paper presented in an International workshop on Development - Oriented Thematic Inter-disciplinary Action Research (DOIT-AR): July 2004, Debub University Wondo Genet College of Forestry.

Issa, A. O. (2004). Practical guide to project writing for students in polytechnics, colleges and universities; Department of Library and information science, Federal Polytechnic, Kwara state Nigeria.

Kajembe, G. C., Nduwamungu, J., \& Luoga, E. J. (2004). The impact of community- based forest management (CBFM) and joint forest management (JFM) on forest resource base and local people's livelihoods: case studies from Tanzania. Commons Southern Africa occasional paper serie, 8, 17.

Macleod, H. M. (1987). Conservation of the Oku mountain forest, Cameroon ICBP Study Report No 15. Cambridge, ICBP

Mohamed, B. S. (2006). Impact of joint forest management on Handeni Hill Forest Reserve and adjacent communities. Dissertation for Award of MSc Degree at Sokoine University of Agriculture, Morogoro, Tanzania.

Moss, C., Schreckenberg, K., Luttrell, C., \& Thassim, E. (2005). Participatory forest management and poverty reduction: a review of the evidence Draft review, ARPIP project, ODI.

Murali, K. S., Murthy, I. K., \& Ravindranath, N. H. (2002). Joint forest management in India and its ecological impacts. Journal of Environmental Management and Health, 13(5), 512-528. https://doi.org/10.1108/09566160210441807

Mbenmben, Y. (2007). Sustaining rural livelihoods in mountain ecosystems: Case study of Oku. Unpublished Long Essay, Department of Geography (ENS) University of Yaounde 1.

Moss, C., Schreckenberg, K., Luttrell, C., \& Thassim, L. (2005). Participatory forest management and poverty reduction: a review of the evidence; Overseas Development Institute: Prepared for the Start-up workshop of the project: Action Research on Assessing and Enhancing the Impact of Participatory Forest Management on the Livelihoods of the Rural Poor. Nairobi, Kenya.

Mustalahti, I. (2006). How to handle the stick: Positive processes and crucial barriers of participatory forest management, Forests, Trees and Livelihoods, 16(2), 151-165. https://doi.org/10.1080/14728028.2006.9752553

Nkembi, L. N. (2003). Participatory Forest Conservation and Sustainable Livelihoods: Banyang-Mbo Wildlife Sanctuary; Quebec City Canada. 


\section{Macrothink}

International Journal of Global Sustainability

ISSN 1937-7924 2018, Vol. 2, No. 1

Ndenecho, N. (2012). Indigenous Knowledge and Plant Resources for the Development of Biotechnologies in Cameroon. AGWECAMS Printers, Bamenda.

Nambu, M. (2001). The Botanical Inventory of the Banyang-Mbo Wildlife Sanctuary. WCS Cameroon Biodiversity Programme, Nguti. Cameroon. Unpublished.

Pulhin, J. M., \& Dressler, W. H. (2009). People, power and timber: the politics of community-based forest management. Journal of Environmental Management, 91(1), 206-214. https://doi.org/10.1016/j.jenvman.2009.08.007

Ravindranath, N. H., \& Sundha, P. (2004). JFM in India: Spread, Performance and Impact. Hyderabad University Press, India.

Scoones, I. (1998). Sustainable rural livelihoods: A framework for analysis. IDS Working Paper 72. Institute of Development Studies (IDS).

Vabi, M. B., Dieunedort, W., Njankoua, M. G. A., Lumumba, T. M., Tchakoa, J., \& Tene A. (2002). The costs and benefits of community forests in selected agro-ecological regions of Cameroon. Cameroon DFID-Funded Community Forestry Development Project (CFDP)/DFID. Yaoundé.

White, F. (1983). The vegetation of Africa; a descriptive Memoir to accompany the UNESCO/ AETFAT/UNSO Vegetation Map of Africa (3 plates). UNESCO, Paris. Prepared by Allard Blom http://www.kew.org/gis/projects/oku-cameroon/results.html

White, P. \& Mustalahti, I. (2005). Finnish forestry assistance: Success story of failure? Analyses of case studies from Sub-Saharan Africa and their possible impacts on poverty reduction. Silva Carelica, 48, 105.

\section{Copyright Disclaimer}

Copyright for this article is retained by the author(s), with first publication rights granted to the journal.

This is an open-access article distributed under the terms and conditions of the Creative Commons Attribution license (http://creativecommons.org/licenses/by/3.0/). 